\title{
9 \\ What was Dr Coombs thinking? Nyirrpi, policy and the future
}

\author{
Nicolas Peterson
}

On 5 May 1972, I set out from Yuendumu with six older Warlpiri men on my first bush trip to visit the Waite Creek area on the southern portion of Mount Doreen Station, more than $400 \mathrm{~km}$ west of Alice Springs. We visited a number of sites, including the important sacred site of Warntungurru, belonging to people of the J/Nampijinpa-J/Nangala patricouple, marked by a metre-high vertical stone $100 \mathrm{~m}$ or so from the creek. We drove south alongside the creek on a station track, stopping off to see various soakages in the creek bed. One of these places was Nyirrpi, ${ }^{2}$ a soakage at the edge of the creek adjacent to a clump of trees that formed a very small island in the middle of it, approximately $125 \mathrm{~km}$ from Yuendumu as the crow flies. It was remote, the nearest occupied place being the station homestead $40 \mathrm{~km}$ to the north.

\footnotetext{
1 I would like to acknowledge many stimulating conversations with Maggie Brady, Paul Burke, Francoise Dussart, Julie Finlayson, Robert Graham, Anna Kenny, Dick Kimber, Mary Laughren, Francesca Merlan, Yasmine Musharbash, Fred Myers and David Nash about issues relating directly to this chapter. I would also like to thank Frank Baarda and Wendy Baarda for their comments and assistance, and to acknowledge how welcoming and helpful they have always been over so many years. Thanks too to Ormay Gallagher for sharing her history of Nyirrpi.

2 Nyirrpi is the correct spelling of the place name. However, when registered with the Government, it was spelt Nyirripi and that is now the name that appears on some maps.
} 
Warntungurru was the conception site of Jilijanka Jampijinpa, which lay at the heart of his patrilineal estate. I did not spend long there but left Jilijanka and Wanyu Jampijinpa to cut slabs from mulga trees in the vicinity from which to make sacred boards. I travelled a bit further south with four other men to a large clay pan, Walyka, still full of water and covered in emu tracks, and then to Kurdjinyungu, which was created by a pair of kangaroos, one a plains kangaroo and the other a hill kangaroo that are celebrated in some versions of the male circumcision rites. As far as I am aware, there was no talk of an outstation at Nyirrpi or elsewhere at the time, although in the following months Jilijanka and his brother indicated that they would like to live there.

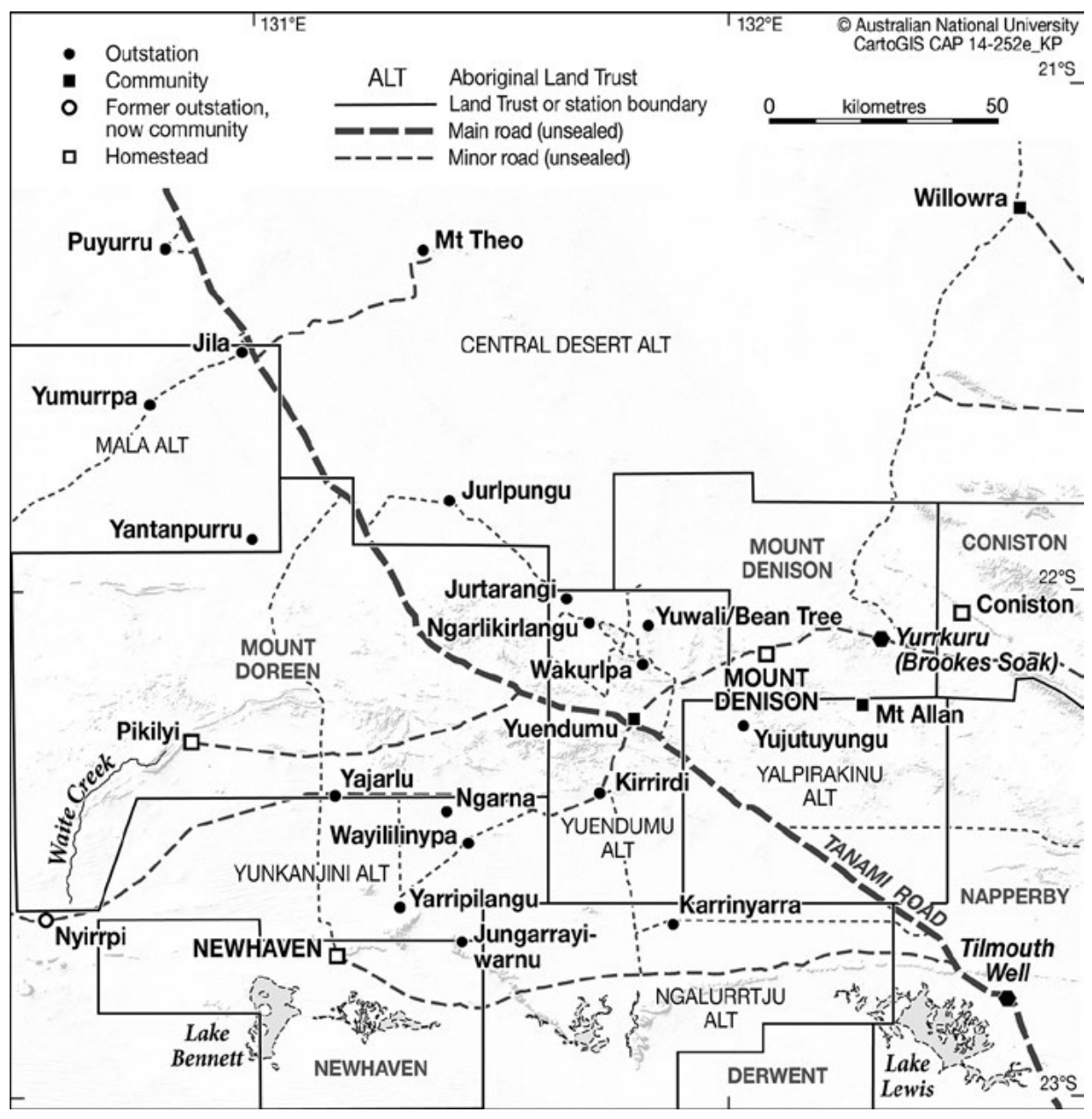

Map 9.1 Nyirrpi in relation to Yuendumuand outstations with infrastructure, although none were currently occupied other than Mount Theo, to which petrol sniffers were taken for rehabilitation at the time of writing.

Source: Karina Pelling, CartoGIS, ANU College of Asia and the Pacific 
Amazingly (that is the correct word), by the 1980s Nyirrpi had become a flourishing small community that is now a quite independent village of about 250 people. Just how this came about and what it says about the envisioned future for and by Warlpiri people, and by extension other remote Aboriginal populations, are what I want to explore.

Nyirrpi would never have happened, of course, if Jilijanka and his relatives were not deeply desirous of and committed to living there, but they had none of the obviously needed formal skills required to marshal government monies and support to get a settlement off the ground. So what was the thinking that put government policy into reverse, that switched from a century of concentrating people into settlements closer to urban centres where they were to learn the skills that would eventually help them take a place in mainstream Australian society ${ }^{3}$ How did it seem sensible to encourage people to live $125 \mathrm{~km}$ more remotely than the already remote community of Yuendumu, $300 \mathrm{~km}$ north-west of Alice Springs? Nyirrpi raises these questions in a particularly apt way, because Dr H. C. ('Nugget') Coombs was not only influential in Aboriginal policymaking at this time, but together with the anthropologist W. E. H. Stanner, he also made a visit to Yuendumu and wrote a report (Coombs and Stanner 1974) on the visit, which, among other things, dealt with the emergent outstation issue in the area.

Although the focus here is on the policymakers, I would, of course, like to know more of the Aboriginal protagonists' views. Even though I made a number of visits to Yuendumu after 1973, my focus was always to the north and it was not until the 1990s that I discovered that a township had grown up at Nyirrpi. As a result, I never did ask any of the original Aboriginal proponents their views, and all are now dead. So the principal sources I have for understanding the Aboriginal perspective are the same departmental records that I am drawing on to get an insight into the thinking and visions of the policymakers and administrators.

\footnotetext{
3 See Long (this volume). Reacting to the proposal for a depot in the Petermann Ranges in January 1959, the Department of Territories in Canberra responded that it was 'necessary to encourage movement to more settled areas' and if the area in the ranges was 'suitable for pastoral purposes just as much opportunity could be provided by making the land available to private enterprise'. Long says that since Paul Hasluck was the Minister for Territories and took a very close interest in Territory affairs, he was probably responsible for the reply, which is really entailed by the policy of assimilation that he strongly espoused.
} 


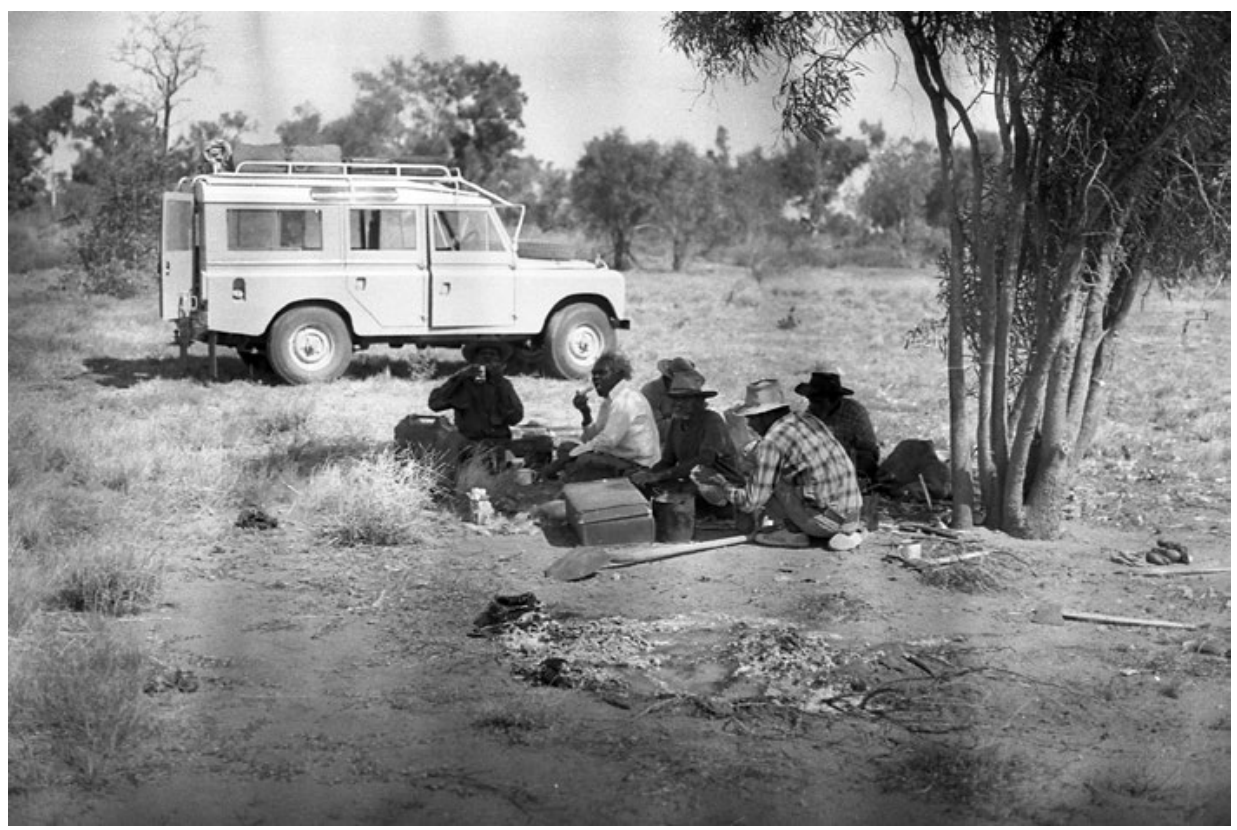

Figure 9.1 Lunch near Nyirrpi on 5 May 1972.

From left to right: Yarrijarriji Jampijinpa, Wanyu Jampijinpa, Jack Japanangga, Jilijanka Jampijinpa, Long Paddy Jangala and Jack Jampijinpa.

Photo: Nicolas Peterson

\section{Initial moves}

Unbeknown to me, in 1970, a close countryman of Jilijanka's and a number of other men had been driven out beyond Nyirrpi to the even more remote location of Ethel Creek, to the north-west, by the superintendent of Yuendumu to leave petrol, water and some food there for a future outstation. The departmental files offer no evidence for the stimulation for the 1970 trip. This was before the Gibb Committee report '[t]o review the situation of Aborigines on pastoral properties in the Northern Territory' (in December 1971), in which recently reformulated government policy was quoted: 'The Government recognises the rights of individual Aborigines to effective choice about the degree to which and the pace at which they come to identify themselves with ... [mainstream] society' (Gibb 1971: 4). And before the 1972 Australia Day speech of Prime Minister William McMahon in which he announced the end of assimilation in very similar terms (Griffiths 1995: 119)-perhaps not surprisingly given that Nugget Coombs was a member of the Gibb Committee and also of the Council for Aboriginal Affairs, which was advising the Liberal-National Party Coalition Government on policy issues in this area. 
There were, however, hints of the outstation movement further north in Arnhem Land, where the development of the North Australian Bauxite and Alumina Company (Nabalco) mine was causing tensions, as Stanner, anthropologist and member of the Council for Aboriginal Affairs, found during his visit to Yirrkala from 18 to 25 November 1969 (Rowse 2000: 81). Other precursors to the outstation movement had existed in north-east Arnhem Land since the late 1940s, where small, bush-living groups were serviced by plane by the Reverend Harold Shepherdson. Djurrpum of the Marapai-Guyula clan became the recognised authority on making outstation airstrips. In 1959, he and his team cleared one on the Koolatong River where the soil was excellent for gardening and there were many crocodiles available in the river to be hunted for their skins. Later in the same year, the team went to Mirrngadja to clear an airstrip, with the first flight in August 1960. There were strips at Caledon Bay, Matta Matta and elsewhere on the coast so that the news Stanner brought back from Yirrkala that people were thinking of moving back to their country late in 1969 because of the mining developments made complete sense locally even if it caught members of the Council for Aboriginal Affairs by surprise (Rowse 2000: 83-84; 2012: 184). The question of whether there was any connection through the administration of what was threatened in Arnhem Land and the readiness of the Yuendumu superintendent a few months later to take people to a remote area to establish an outstation is unanswered.

On 5 February 1973, the Warlpiri man who had been a key party in the 1970 trip approached me to write to the Minister for Aboriginal Affairs asking for a bore to be put down in his Ethel Creek country (see Appendix 9.1). By the end of the year, this man, Jungarrayi, had had assistance, presumably from the community adviser at Yuendumu, to put in for a grant for a vehicle in relation to the desire 'of himself plus 20 other men and their families [for] ... an outstation to be established at Ngarapula [Ngarapalya]'. ${ }^{4}$ A year later, in March 1974, the people in the Ethel Creek group, who also had a connection to Nyirrpi, formed their own separate group as even they felt Ethel Creek was too far away. ${ }^{5}$

By 1974 the funding for outstations was well established. This was a direct consequence of McMahon's 1972 Australia Day speech about the right to choice of lifestyle, and stimulated in Arnhem Land at least by the questioning associated with the visits of the Royal Commission into Aboriginal Land Rights (the Woodward Commission) to communities, when people were asked about the use they would make of the land once they had it back.

4 National Archives of Australia (hereinafter NAA): F1, 1973/9595, Movement of Wailbri Sub Group (Banjo Jungarai) to Ngarapula west of Yuendumu (Ethel Ck) (Walwuma): 92. NAA can be accessed online.

5 ibid.: 4: 155. 
In January 1974, the criteria for funding of such resettlement were:

1. number of people

2. extent of organisation shown by group
a. voluntary action
b. non-voluntary action

3. identification of felt needs and priorities as expressed by the community

4. extent to which group proposes to be self-sustaining (cash inflow, food and satisfaction of other basic needs)

5. potential of project to be self-sustaining

6. infrastructure of communication links available to community

7. social visibility. ${ }^{6}$

The Department of Aboriginal Affairs (DAA) office in Alice Springs had received instructions to support such groups from Canberra, provided they met these criteria. $^{7}$

Things moved quite quickly for the members of the Nyirrpi group. They formed their own committee, the Nyirrpi Town Council, ${ }^{8}$ but as a newly formed group in March 1974 it seems clear that their ideas about the outstations were very vague as far as the DAA was concerned, especially in relation to how they would support themselves. ${ }^{9}$ But by May people were much clearer about what they would do at Nyirrpi. They indicated they would run some cattle and so would need materials for fencing, a truck and a shed. They would also establish a vegetable garden and probably build an airstrip. ${ }^{10}$ Some people would live there permanently and others would use it as a holiday spot.

\section{The Coombs-Stanner report on Yuendumu}

At this point, Coombs' ideas on policy as they relate to the Warlpiri become quite explicit. He decided in the light of the 'tensions and apparent breakdown in social control' in some remote communities under self-determination (Rowse 2000: 138) that he would visit Yuendumu and Hooker Creek, subsequently renamed Lajamanu, to find out what was going on. Stanner joined him on the trip and together they wrote and published their Report on Visit to Yuendumu and Hooker Creek (Coombs and Stanner 1974). A dual concern runs through

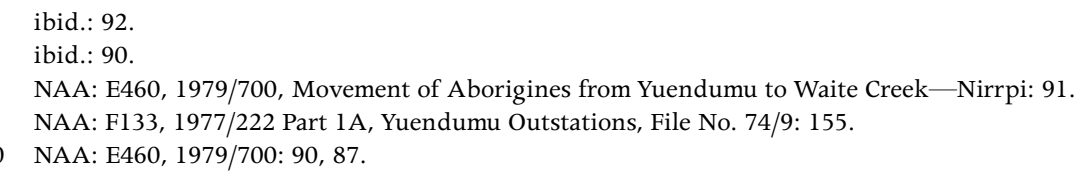


the report. On the one hand, they were concerned that Warlpiri people had the option of preserving their 'traditional Aboriginal life style' (Coombs and Stanner 1974: 3), but on the other, the more dominant concern was with issues of development, the management of alcohol and improving Warlpiri involvement in the running of the new community council.

In respect of preserving the option of the traditional lifestyle, they recommend that:

Policy be directed to ensuring that Aborigines are not forced by economic and social pressures to accept a European style of life if they would prefer a simpler more traditional style: i.e. that Aborigines be allowed and helped to adapt freely to their own requirements and circumstances [and] such white Australian practices as they consider to be of value to them. To this end-

a. decentralisation moves initiated by Aborigines should be assisted and efforts made to keep the new groupings small and closer in style to the traditional Aboriginal way;

b. even when European style housing is available there should be the choice of a camp which is simple and traditional but sanitary and visually pleasant;

c. offers of employment should be made which do not necessarily require full entry into the work force-e.g. for a shorter working week, for periods of some weeks or months interrupted by periods of unpaid leisure, by contracts let to groups or communities;

d. efforts should be made to develop sources of income for Aborigines compatible with the chosen life style and if possible deriving impetus from it (e.g. traditional artefacts or crafts based on a traditional skill or design). (Coombs and Stanner 1974: 3-4)

Stanner's surprise at just how intact local traditions were in Yirrkala in November 1969 (Rowse 2000: 81) was probably mirrored at Yuendumu, although nothing is said explicitly about this in the report. However, the report speaks of the 'vigorous' ceremonial life and ground paintings of 'great beauty' still being created and used for the instruction of the young men; that generally the influence of Aboriginal tradition appears to remain strong; and that almost all of the decentralisation moves contemplated are concerned at least in part with protection of, and opportunities to visit, sites of importance (Coombs and Stanner 1974: 14, see also p. 22).

This all suggests that they were impressed with the strength of Warlpiri culture, which I can certainly vouch for at that period, but it also suggests that like many outsiders at that time they were talking to the older men and women in the community and probably more influenced by helping them realise visions of the future that were heavily influenced by the past, rather than thinking of 
the younger generations and the future that was facing them. Indeed, one of the weakest features of the report is the information under demography that presents no analysis of the structure of the population other than providing the gender ratio, rather than looking at age cohorts and what they might suggest about population growth.

I think this reflects the thinking behind much policy formation coming out of the Council for Aboriginal Affairs: catering to the needs of the older generation who would never need to face a lifetime dealing with the market economy post de-institutionalisation - that is, since the creation of community councils in the 1972-75 period. The thinking behind the report is gradualist, its most forwardlooking element being the concern with making the councils work better. The issue of what the growing population would be doing in 10 or 20 years is nowhere explicitly addressed, nor is there any anthropological insight into the social and cultural dynamics of the situation, or thought given to Aboriginal motivation. It is assumed that in getting the political structure, Warlpiri would be enabled to choose their path into the future.

Two paragraphs are particularly revealing:

Some see this acquisition of more and more sophisticated and complex needs and demands as wholly desirable and as evidence of Aborigines achieving a higher level of civilisation integrating more completely into our society and being motivated more strongly to accept the obligation and the discipline of work.

But it cannot be denied that it progressively tends to impose on the Aborigines concerned a way of life which in some respects is distasteful to many of them, which brings them together in larger communities than their traditional social disciplines can readily manage. (Coombs and Stanner 1974: 19-20)

There is an extensive discussion of a number of sensible and practical economic possibilities in respect to craft, environmental management, cattle work, mining, getting the majority of young people into paid employment and the involvement of Aboriginal people in the provision of community services, building infrastructure and maintenance (Coombs and Stanner 1974: 5, 11). This manifests a clear concern with young men in particular (Coombs and Stanner 1974: 19), in relation to providing training and work that generated income for the community. Even so, decentralisation also receives considerable attention, and they comment:

It is our view that policy should be directed to facilitating this movement for those Aborigines who wish to take part in it. This is necessary if Aborigines are to have effective choice as to whether and at what pace they wish to accept the European way of life. (Coombs and Stanner 1974: 20) 


\section{The establishment of Nyirrpi}

A major issue facing the group was the actual location of Nyirrpi. The problem was that Nyirrpi, chosen for its enduring soakage water, was on Mount Doreen Station, owned by W. Braitling, who did not want an outstation on his land. So either there had to be an excision from the station area or the location of the outstation would have to be moved beyond the southern boundary to an area of vacant Crown land. ${ }^{11}$ A related issue was the location of the access road to Nyirrpi, which Braitling wanted to be off the station area as well.

The Yuendumu community adviser at the time, Graham Castine, was diligent in helping the Nyirrpi leaders write letters, and on 8 May 1974, named the 21 men who were involved in wanting to set up the outstation and indicated that between them these men had 35 wives and 53 children. By July 1974, the demand to establish new outstations among the people at Yuendumu was developing momentum and two more groups, in addition to the Ethel Creek group, were seeking money for vehicles. Coombs and Stanner mentioned that there were about 130 people who wished to move $90 \mathrm{~km}$ north of Yuendumu to Mount Theo in the heart of the Tanami Desert: as they comment, 'the Tanami desert is extremely arid' and the 'project seems difficult' (Coombs and Stanner 1974: 21), and then there was the Nyirrpi group, said to number approximately 60 people. $^{12}$

Vehicles for all three groups were approved in October 1974 but they were quickly a source of problems because in the first five months they were used continuously for 'flagon runs' and only once for a trip to an outstation location. Use of the Nyirrpi vehicle was brought to an end when it was impounded for being involved in a fatal accident. ${ }^{13}$ The then community adviser, Roger Styles, indicated that he had made it clear that it was not his role to control the use of the vehicle, as he was being asked to, but that the leaders of the groups had to be prepared to take on the responsibilities that went with running an outstation. ${ }^{14}$ Further, it was a requirement that people showed they were prepared to stay at their outstation. It was recognised that an obstacle to the appropriate use of the vehicles was that there were no appropriate roads and that many Yuendumu residents had been tied up fighting bushfires, preventing them either building roads or occupying the outstation. Later, when it emerged that sales tax was

11 ibid.: 87.

12 NAA: F1, 1973/9595: 80.

13 ibid.: 24, 12; 7: 37.

14 NAA: E460, 1979/700: 57. 
owing on the vehicle, it was required that each group contribute at least $\$ 200$ of their own income to pay this to show that they were committed to their outstations. $^{15}$

On 8 and 9 April 1975, the new community adviser, Paul Ashe, took the men out to Nyirrpi using the Museum Society's vehicle, as he had not been allocated one as part of his job. ${ }^{16}$ The purpose of the meeting was to speak with Braitling, the Mount Doreen Station owner, to see if it was possible to have the outstation at Nyirrpi, but Braitling made it absolutely clear that he was not keen on the idea.

April was a turning point for many older people at Yuendumu. There had been a lot of breaking and entering. ${ }^{17}$ Pressure was brought to bear on the council to do something about it, particularly by the school. A range of methods was tried:

Including seeing the parent of the children, payment of compensation by parents, chastising the children in front of their parents, patrols around the Settlement etc. etc., all of which had very little effect. Finally it was decided that the offenders, if caught on two consecutive occasions for breaking and entering, would be taken bush for a period of time, preferably in their own tribal country. It was therefore resolved that initially three children who were second offenders would be taken bush accompanied by a handful of old men. ${ }^{18}$

Much to the surprise of the community adviser, at a council meeting on 11 April, the council had a list of 27 children, both first and second offenders, whom they wanted to take bush. It seems that most were accompanied by their parents because of the latters' concern about their welfare there. Because the community adviser's job did not come with a vehicle, he was unable to check what was going on at the outstations as a consequence of this decision, but he had reports shortly after the move that about 100 people were camped at Julpungu, the closest of the outstations to Yuendumu, under the leadership of Jimija Jungarrayi. On Saturday, 12 April, the day after the council meeting, about 60 people set off for Nyirrpi, but their transport broke down at Cusacks Bore. ${ }^{19}$

The party got no further than the bore, but in June 1975, men from the group were cutting a new line of road just to the south of the Mount Doreen Station boundary on vacant Crown land and had completed the first $25 \mathrm{~km}$ of the total $125 \mathrm{~km}$ required. By the end of July, the men had completed $70 \mathrm{~km} .{ }^{20}$ In reporting this work, the community adviser commented that the Nyirrpi

15 ibid.: 15.

16 ibid.: $36-34$.

17 NAA: F1, 1973/4638, Yuendumu Disturbances: 10, 7, 9, 16.

18 NAA: F133, 1977/222 Part 1A: 106

19 ibid.: 105.

20 ibid.: 4, 77, 60-62. 
group 'is the only group that has shown any real initiative in trying to establish an outstation'. He also pointed out that without a vehicle it was difficult for him to monitor the outstation movement. ${ }^{21}$

Reflecting on how the outstation movement could be better managed on 30 October 1975, the community adviser commented that it was a vital mistake to supply vehicles and trailers to the groups before they had indicated any physical move to outstation areas. This was because it created the impression that the setting up of outstations was the responsibility of the Government and virtually the only responsibility that the people had was to move to the area. ${ }^{22}$ He was of the opinion that groups might still move even when they realised no more supportive resources would be forthcoming until they left Yuendumu. Indeed, in December 1975, it was reported that the Nyirrpi men were spending up to six weeks at a time out at Nyirrpi but that they rarely took their wives or children because until the bore drilling for a long-term supply of water had taken place there could be no permanent population. ${ }^{23}$

In August 1976, the regional director of Aboriginal Affairs wrote a curt file note saying he was 'somewhat staggered to be told when visiting Yuendumu on the 29th July that groups had moved out to two outstations', Ethel Creek and Mount Theo, because he had heard nothing from the community adviser about this in the previous nine months. ${ }^{24}$ This prompted a four-page report from the community adviser, which indicated that the regional director's understanding was wrong. No one was at the places mentioned and the only people beyond Yuendumu were the 30-50 people living at Nyirrpi. Things were looking good for them because not only had adequate water been found at a depth of about $140 \mathrm{~m}$ to the south of the Mount Doreen Station boundary, but also Braitling had no objection to them camping at the Nyirrpi soakage on the station, where they had been since mid-May, until they could move to the new location. Further, the Yuendumu Social Club was providing financial support and the group was existing on a grant of $\$ 40$ per fortnight on top of their own pensions and child endowment payments. ${ }^{25}$

At this date the community adviser estimated that the numbers of people who would live at the various outstations would be: Nyirrpi, 50-70; Julpungu (Djulpung), 30-40; Nyinyiriplangu, 30-40(?); Wanuyaka (that is, Mount Theo), $30-40(?) \cdot{ }^{26}$

\footnotetext{
ibid.: 60-62.

ibid.: 42 .

ibid.: 34 .

ibid.: c25.

ibid.: $21 \mathrm{c}-\mathrm{d}$.

ibid.: $21 \mathrm{~d}$.
} 
By October 1977, people had been living at Nyirrpi for two years and it was the most stable of all the outstations, ${ }^{27}$ and in that same month a bore was equipped $11 \mathrm{~km}$ to the south of the Nyirrpi soakage outside the southern boundary of Mount Doreen Station. ${ }^{28}$ It is not clear when the Nyirrpi people moved from Nyirrpi to Jitilparnta, but it was probably sometime in late 1977 or early 1978, and by October 1977, they were back at the original Nyirrpi because of the unserviceability of the windmill at Jitilparnta. ${ }^{29}$ Because the outstation was known to everybody as Nyirrpi, the decision was made to keeping calling the permanent outstation at Jitilparnta, Nyirrpi, which I will occasionally call Nyirrpi 2 if clarification is needed.

Roy Fry Jangala spelt out the list of needs to make Nyirrpi 2 viable. These included the grading of the road from Kerridi to Nyirrpi, an airstrip, a new vehicle to replace the four-year-old one and a small tractor. Gardens had been established there but the dwellings were only of natural materials and tarpaulins. At that time, 10 members were receiving unemployment benefits; ${ }^{30}$ however, the population was still only 20 at Nyirrpi, but the need for tents was spelt out.

In July 1978, Susan Kesteven visited Yuendumu, at which time there were just two outstations, one at Julpungu and the other at Nyirrpi, but three more were established four months later (Kesteven 1978: 49): these were at Jila, Yarripilangu and Ngana. Elspeth Young also recorded an outstation at Kunajarrayi in 1981 (see Young 1981: 73-74). When Kesteven (1978: 51) visited the outstation, the bore at Nyirrpi 2 was broken and the people had moved back to the soak water at the original Nyirrpi site, where there were eight humpies. There were 40 people there: 13 men, 18 women and nine children, but no one between the ages of five and 25 other than two young wives (Kesteven 1978: 52). Roy Fry produced a map showing how he envisaged Nyirrpi, including with a vegetable garden. In September a new store manager at Yuendumu started store runs to Nyirrpi funded by social security. At that time there were six people receiving child endowment totalling $\$ 292$ per fortnight, three old-age pensioners, one invalid pensioner and nine receiving unemployment payments. Elspeth Young also visited Nyirrpi in 1978 and records that the fortnightly income at the time of her visit was $\$ 1,900$, with the per capita income working out at $\$ 90$ (1981: 73). There were 21 people there at the time she visited. Both Young (1981: 73) and Kesteven (1978: 66) report that the men spent much of their time hunting. On the basis of her quite short visit, Kesteven makes two observations. First, the emphasis on including vegetable gardens in outstation applications for funding

27 ibid.: 112

28 ibid.: 112.

29 ibid.: 86.

30 ibid.: $86-85$. 
was because people had the impression that the Government wanted outstations to have an economic base. Her implication is that the actual commitment to running gardens was slight. The other observation was about women's attitudes to outstations. She felt that women were slightly less enthusiastic about moving out, especially the younger ones and those who had jobs at Yuendumu. However, what they liked about the outstations was that they were quiet, there was no drinking and they were a good place to mourn - widows having to live separately and observe silence for extended periods (Kesteven 1978: 70-71).

A crucial development took place in April 1979. Dennis Jacobsen of the United Pentecostal Church (UPC) contacted the Department of Aboriginal Affairs about the possibility of establishing a mission at Nyirrpi. He claimed that he had been approached by Edwin Ross and Norman, who had invited him to visit Nyirrpi. ${ }^{31}$ The Yuendumu Council took exception to the representative of the UPC going to Yuendumu and Nyirrpi without permission and 'chastised' the Nyirrpi people for not observing the proper procedures, but they relented and asked the Central Land Council (CLC) to issue a permit for four months to allow a mission to be established at Nyirrpi, which would be supported by resources from the metropolitan areas.

A meeting was held in Alice Springs at the Department of Aboriginal Affairs office on 10 May 1979 to explore the issue further. Present were Harry Nelson, the Reverend Dennis Jacobsen of Alice Springs, the Reverend Peter Hargraves from Canberra, John Harwood of Alice Springs, Brailsford from the DAA and Charlie (Jilijanka?) and Tiger Japaljarri from Nyirrpi. ${ }^{32}$

The arrival of Brother John, as he became known, to take up residence there was key to Nyirrpi's success as it provided the community with a scribe and advocate who not only could deal effectively and persistently with the Government but who also had a considerable degree of independence because of his church funding. His effectiveness was clearly seen as a threat by the Baptist missionary at Yuendumu (see Eller 1992). In August, the Reverend Kingston launched a personal attack on Brother John whom he said was not fit to live in a remote community. However, the community adviser believed that the people at Nyirrpi wanted him to stay, and there seems no doubt about this. ${ }^{33}$ Indeed, by the end of the year, he had baptised about 18 people ${ }^{34}$ and was later that year elected to the Yuendumu Outstation Council over the concerns of the DAA officer, and his superior, who indicated that the Government would have to wait until the Aborigines concerned 'see the light' ${ }^{35}$ The UPC had provided Henwood with

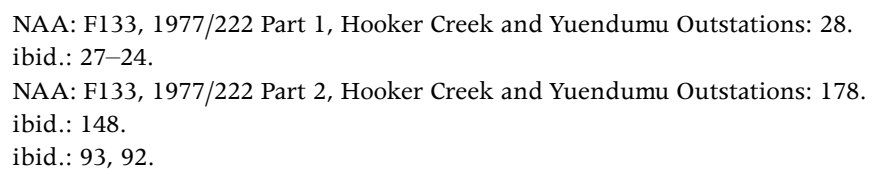


funds for a $5.5 \mathrm{~m}$ caravan and a substantial shed. While the visiting DAA officer felt the camp was not 'particularly clean', ${ }^{36}$ he noted that the bore and equipment were well maintained and clean, and that Henwood was away hunting with the men. This hints, I think, at the foundations of Nyirrpi's success. With Henwood there, people could be certain that there would be water, equipment would work and that he would ensure the flow of supplies. This seems to be indirectly confirmed in a note from Jeremy Long, then deputy secretary to the DAA, on a visit to Nyirrpi in August 1981, who learnt from Henwood that he, Henwood, had been in touch with various government departments on issues ranging from seeking a solar pump for the water supply and obtaining a radio frequency for outstations to applying for Nyirrpi to be dry (that is, a no-alcohol area). There was also the matter of progressing the building of an airstrip there. ${ }^{37}$ By November 1981, the Outstation Council had agreed to fund a shed as a shop at Nyirrpi, which was run by Ormay Gallagher for a period (Gallagher n.d.). Significantly, the note asking for the DAA to organise the purchase of the shed is signed by three Aboriginal men but the postal address is 'Rev J. R. Henwood, P.M.B. 16, Waite Creek, Via Yuendumu, NT 5751'. ${ }^{38}$ Brother John became the storekeeper and took responsibility for supplies and transportation (Eller 1992: 9). Such a store was essential as there were more than 100 people living at Nyirrpi by January 1982 and the DAA was finding it difficult to continue to insist that emergency evacuations could be carried out via the Vaughan Springs airstrip $65 \mathrm{~km}$ to the north because the road was so bad that it was quicker to go to Yuendumu, two hours away. ${ }^{39}$

In 1984, the DAA was persuaded to erect five two-bedroom sheds there, and in 1985 the Centre for Appropriate Technology (see Mayne 2014) erected six pit lavatories. In the same year, the Department of Education started funding an outstation teacher because there were more than the minimum number of schoolchildren living at Nyirrpi permanently. This position was taken by Wendy Baarda from Yuendumu, who would teach at Nyirrpi on Mondays and Tuesdays, return to Yuendumu on Wednesdays to prepare lessons and then drive back to Nyirrpi on Thursdays before returning to Yuendumu on Fridays. Wendy was a pillar of the bilingual program and the first year of her teaching beneath a tree was dedicated to Warlpiri literacy. She was assisted by Nyirrpi residents Pauline Gallagher and Fiona Dixon. After two years, some of the older children could read and write Warlpiri very well and were also reading in English. Two years later, a permanent building had been erected for the school (Gallagher n.d.). Nyirrpi was clearly on the way to becoming a permanent settlement. Although specific evidence has not yet been found to show Brother John's hand in the

\footnotetext{
36 ibid.: 178.

37 ibid.: 58, 60 .

38 ibid.: 25.

39 ibid.: 19.
} 
housing, it seems highly likely that he had a key role. Also important was the support from the Outstation Council and its employee Peter Bartlett for the building of the first houses, and in 1985-86 the first two substantial houses were built (Morel and Ross 1993: 39). With the Government now providing housing and education, the servicing of the community, and its future, took on a life of its own.

Plans for outstations at Yampiri, Yaripilung, Mount Theo in the Tanami Desert proper, and at Ngalikirlungu, although being seriously considered in the late 1970s, never resulted in the establishment of long-term settlements, even though it was estimated that more than 100 people might move to Mount Theo and more than 50 to Ngalikirlungu Bore. ${ }^{40}$

\section{Conclusion}

Without doubt Nugget Coombs was the key influence in policy formation in the period 1967-76 when he chaired the Council for Aboriginal Affairs, although both Stanner and Dexter were clearly also important influences on his thinking. This period saw the development of the land rights, self-determination and outstation policies, all of which have been pejoratively characterised by the right as the Coombs socialist experiment (see Rowse 2012: Ch. 10) and responsible for segregating remote Aboriginal Australians from the mainstream. In the views of people like Peter Howson, Geoffrey Partington, Gary Johns and more recently Helen Hughes, it was only in 1996 with the election of the Howard Government that policy began to get back on track, with its biggest achievement being the abolition of the Aboriginal and Torres Strait Islander Commission (ATSIC) in 2004 and the Intervention in 2007. In their view, this marked the end of the separatist policies, fuelled by a romantic desire to preserve tradition, that were stopping people being integrated into the mainstream. In the extreme views of Helen Hughes, all that was required was getting the economic incentives right, including withdrawing support for the ambiguously described homeland communities to encourage people into the urban centres.

Tim Rowse, in his analysis of Nugget Coombs' legacy in Indigenous affairs, presents a much more complex and nuanced picture. His key point that all policies in Aboriginal affairs are experiments, including those of the right, is very well taken (Rowse 2012: 187), as is the evidence for Coombs being openminded, leading him occasionally to adopt some strange ideas (for example, ethology; see Rowse 2012: 180-3). The overarching element of his approach was that Aboriginal people should have a choice (Rowse 2012: 187), and under the 
anthropologically conservative views of Stanner, Coombs was a strong advocate for continuity, as reflected in the view that the retreat of the people of Yirrkala back to their homelands was a 'wise passivity' (pp. 186, 187). It also seems clear that both men underestimated the rate at which things would change in the future.

While the strong emphasis placed on Aboriginal choice by Coombs seems entirely admirable, it does come with a downside. It relieved policymakers of direct responsibility for facing up to what might happen in the future while assuming that the people themselves were in a position to choose realistically about the degree to which and the pace at which they came to identify themselves with mainstream society. It gives no consideration as to exactly what the choices were between or how they might appear from the point of view of people like those at Yuendumu or Nyirrpi, to whom the world clearly looked, and still looks, quite different from how it seemed from a national policy perspective. In some ways, it was a policy position that shares something with that famously recommended by Donald Thomson and Olive Pink, who both argued for leaving people to pursue their own life on their own terms: in all three cases it was a policy of deferral motivated by deep humanistic concerns.

In Donald Thomson's case, writing in 1937 (Thomson 1939), he recognised change as inevitable but optimistically thought that the science of anthropology and its understanding of change would, in the future, provide a much smoother and pleasanter transition for Aboriginal people than in the past. But, by 1974, not only had even the remotest-dwelling Aboriginal people developed a certain consumer dependency, but there had also been a quantum change in the attitude to Indigenous people and their rights in the community at large. There was much greater interest in the lot of remote Aboriginal people and pressure from many quarters, both national and international, to improve the material circumstances of their lives.

So why would people developing social policy for Aboriginal people want to postpone facing inevitable issues? One possibility was that Coombs saw the outstations as refuges for the older generations and more conservatively oriented Aboriginal people whose 'social disciplines', as he put it, could not easily handle life in the large communities. Indeed, Young (1981: 71-2) reports that 20 per cent of outstation residents in the Yuendumu area in 1978 were aged over 60, whereas people in this age bracket made up only 6 per cent of the Yuendumu population. However, it is not clear if he believed that once the older generation had died, most outstations would disappear. Another possibility is that there was no clear and acceptable policy to suggest that addressed the long-term issues: they were just too difficult, especially in the changed social and political situation that 
gave Aboriginal people more voice in the policies that affected them. Indeed, one might even suggest that policymakers more generally found it difficult to envisage the future for Aboriginal people in remote desert Australia.

Nevertheless, it is surprising that the long-term future of the population in the Yuendumu area was not canvassed in the Coombs-Stanner report. Although there is an explicit concern with younger people learning the discipline of work expected in a market economy, and a concern with projects that could generate some income, there is no evidence to suggest that Coombs and Stanner thought they were setting up Yuendumu as an economically viable outback town, especially given the emphasis on decentralisation. The most forward-looking aspect of the report is the concern with turning the council into an effective instrument for the self-administration of the community - something that was proving more difficult than they had expected (Coombs and Stanner 1974: 23), in particular because the council was not adequately addressing the difficulties around alcohol. Indeed, it seems clear that the council had neither taken on the responsibilities previously exercised by the superintendent nor internalised the role and functions of the superintendent more generally as now its own.

I would suggest that policymakers still face this problem, which is a manifestation of an emergent problem at a world scale: the issue of populations that are surplus to the labour requirements of their national economies. In Australia, this does not just apply to Aboriginal people, but also, for example, to other workers such as those in the Holden car plants and other areas of manufacturing. This in turn raises the question of whether life in an outstation or remote Aboriginal community can provide a desirable long-term form of dependency in the twenty-first century. If so, Nyirrpi has a long if unclear future. Policymakers, it appears, are still faced with the same problem that faced Coombs in 1974 but now the difficulties are more explicitly on the agenda.

\section{References}

Coombs, H. C. and Stanner, W. E. H. 1974. Report on Visit to Yuendumu and Hooker Creek. Canberra: Australian Government Publishing Service.

Eller, J. 1992. Pentecostalism and its relation to traditional and contemporary social organization in Warlpiri society. Unpublished paper. Australian Institute of Aboriginal and Torres Strait Islander Studies, Canberra.

Gallagher, O. n.d. Nyirrpi-kirli. Unpublished typescript. Yuendumu School, Yuendumu, NT. 
Gibb, C. A. 1971. The Report of the Committee to Review the Situation of Aborigines on Pastoral Properties in the Northern Territory. Canberra: Government Printer.

Griffiths, M. 1995. Aboriginal Affairs: A Short History 1788-1995. Sydney: Kangaroo Press.

Kesteven, S. 1978. A sketch of Yuendumu and its outstations. Unpublished MA thesis. The Australian National University, Canberra.

Mayne, A. 2014. Alternative Interventions: Aboriginal Homelands. Outback Australia and the Centre for Appropriate Technology. Adelaide: Wakefield Press.

Morel, P. and Ross, H. 1993. Housing Design Assessment for Bush Communities. Alice Springs, NT: Tangentyere Council \& NT Department of Lands, Housing and Local Government.

Rowse, T. 2000. Obliged to be Difficult: Nugget Coombs' Legacy in Indigenous Affairs. Cambridge: Cambridge University Press.

Rowse, T. 2012. Rethinking Social Justice: From 'Peoples' to 'Population'. Canberra: Aboriginal Studies Press.

Thomson, D. 1939. Report on Expedition to Arnhem Land 1936-7. Canberra: Government Printer.

Young, E. 1981. Tribal Communities in Rural Areas: The Aboriginal Component in the Australian Economy. Canberra: Development Studies Centre, The Australian National University. 


\section{Appendix 9.1}

The letter with explanatory notes written with my help and sent from Yuendumu to the Minister of Aboriginal Affairs in February 1973.

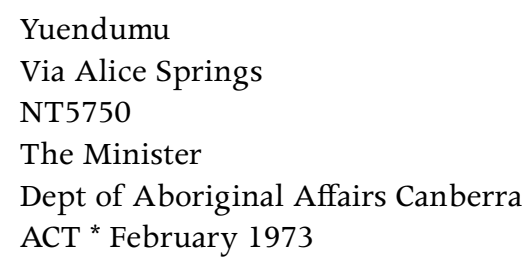

We want to sit down in our country where our fathers' fathers came from. Those men were Pupuwana, Panmawarnu, Mantarkunya, Wararipatu and Raparinyinwana.

We went to our country with Bill Frazier and left drum water and petrol. He want to make new settlement there for we. Too many people in Yuendumu and we get sick all the time.

We want a bore at Yinyiripalangu. We like to go there for holiday and to work there if you help us.

Yours sincerely

Banjo Jungarrayi.

Explanatory note: Yinyiripalangu is 47 miles [76 km] west of Vaughan Springs on Ethel Creek in the Lake Mackay Reserve (Lake Mackay sheet 5152-11 301233). In 1970 a government patrol led by the then superintendent of Yuendumu, Bill Frazier, chose Yinyiripalangu as a possible site for an outstation. Supplies of food, water and petrol were left there by the patrol.

Yinyiripalangu is in the heart of Walpiri country and a bore here would make it possible for many people to return to their own country for both short visits and more permanent stays.

* Dated 5 February in the copy in my field notes, but dated 7 February 1973 according to the letter that Banjo received on 17 May 1973 from the minister in reply to the original letter and a follow-up telegram sent on 14 March because nothing had been heard for six weeks. ${ }^{41}$ 
This text is taken from Experiments in self-determination: Histories of the outstation movement in Australia, edited by Nicolas Peterson and Fred Myers, published 2016 by ANU Press, The Australian National University, Canberra, Australia. 